\title{
Effect of Tillage Practice on Soil Moisture Retention under Three Selected Cowpea Varieties
}

\author{
R. N. Khaemba ${ }^{1^{\star}}$, J. M. Kinama ${ }^{1}$ and G. N. Chemining'wa ${ }^{1}$ \\ ${ }^{1}$ Department of Plant Science and Crop Protection, University of Nairobi, P.O.Box 30197, 00100 \\ GPO, Nairobi, Kenya.
}

Authors' contributions

This work was carried out in collaboration between all authors. Author RNK designed the study, performed the statistical analysis, wrote the protocol and wrote the first draft of the manuscript. Authors GNC and JMK managed the analyses of the study. Author RNK managed the literature searches. All authors read and approved the final manuscript.

Article Information

DOI: $10.9734 /$ IJPSS/2017/32781

Editor(s):

(1) Ni Xiang, Entomology and Plant Pathology, Auburn University, Alabama, USA (2) Fatemeh Nejatzadeh, Department of Horticulture, Faculty of Agriculture, Khoy Branch, Islamic Azad University, Iran.

Reviewers

(1) Yucel Tekin, Uludag University, Turkey.

(2) Valentin Kosev, Institute of Forage Crops, Pleven, Bulgaria.

Complete Peer review History: http://www.sciencedomain.org/review-history/19483

Original Research Article

Received $15^{\text {th }}$ March 2017

Accepted $21^{\text {st }}$ April 2017

Published $12^{\text {th }}$ June 2017

\section{ABSTRACT}

Aim: To evaluate the effect of tillage practice on soil moisture retention under three cowpea varieties.

Study Design: The treatments were laid out in a randomized complete block design with a factorial arrangement and replicated three times.

Place and Duration of Study: The experiment was conducted at St. Theresa farm and Nakamane irrigation scheme in Turkana county between November 2014 and January 2015.

Methodology: Treatments comprised three tillage practices: conventional tillage (control), conventional tillage + mulch, and zero tillage and three cowpea varieties: M66, K80, and Kenkunde. Soil samples were collected using an auger $(25 \mathrm{~mm}$ internal diameter) from near randomly selected 5 plants at the depth of $15 \mathrm{~cm}$ in all treatments at an interval of 7 days. The gravimetric moisture was determined using the $\mathrm{FAO}$ equation.

Results: Tillage + mulch and zero tillage conserved $37.07 \%$ and $31.63 \%$ more moisture than conventional tillage at St Theresa demo farm, respectively. At Nakamane irrigation scheme, zero 
tillage retained more moisture content of $33.02 \%$ followed by conventional tillage + mulch at $32.24 \%$ as compared to conventional tillage. Significant interaction was realized between tillage practice and variety at Nakamane experimental site only. The main effects of variety had no effect on moisture retention.

Conclusion: Tillage practice has significant effect of moisture retention in Turkana county. Any cowpea variety established has no effect on moisture retention. A broader use of tillage practices and varieties is advisable for further studies.

Keywords: Cowpea; moisture retention; tillage.

\section{INTRODUCTION}

Tillage is widely known to affect crop available moisture [1]. Despite high soil water retention due to zero tillage, crop performance has not consistently shown to be better than conventionally grown crops due to the influence of soil type, tillage depth and soil conditions such as moisture content at the time of tillage and prevailing climatic conditions [2]. Tillage impact on crop yield is related to its effects on root growth [3], soil water content and nutrient use efficiencies [4]. Whereas no till is ideal in moisture deficient soils, conventional tillage is be more suitable where rainfall is adequate [5]. Tillage has an effect on sustainable use of soil resources [6]. Although conventional tillage modifies soil properties such as moisture content. It is also associated with negative effects such as erosion and soil infertility [7] as compared to no-tillage methods [8]. As a result, there is more emphasis on conservational and no-tillage practices [9]. Mulch application has been observed to enhance soil moisture storage by accumulation of organic matter and improvement of soil structure [10]. As observed [11], conventional tillage + mulch reduces evaporative soil moisture loss to between $5-10 \%$ providing 20-25 $\mathrm{mm}$ transpiration in sole cowpea as opposed to conventional tillage which contributes to soil degradation, soil water loss and poor environmental management $[12,13]$. The use of no till was reported to have advantageous effects on soil moisture retention [12,14]. Based on these reasons, it was necessary to investigate on tillage practice effect on soil moisture content in Turkana County where crop available water is at a premium due to erratic rainfall. In addition, varieties are reported to contribute to soil moisture retention [15] which necessitated the need to evaluate their possible influence on moisture conservation in Turkana County.

\section{MATERIALS AND METHODS}

\subsection{Experimental Site Description}

The field experiments were carried out at St. Theresa demo farm and Nakamane irrigation scheme along Turkwel river in Turkana County, North west of Kenya. The field stations are within an elevation range of $597 \mathrm{~m}$ to $800 \mathrm{~m}$ above sea level with an annual rainfall of $150 \mathrm{~mm}$ to 500 $\mathrm{mm}$ and a temperature range of $2^{\circ} \mathrm{C}$ to $38^{\circ} \mathrm{C}$. The predominant soils in St Theresa demo farm and Nakamane irrigation scheme sites are undifferentiated tertiary volcanic soils, derived from colluvial and alluvial deposits. The soils are shallow to moderately deep, well drained and dark reddish brown/dark greyish brown in colour. The soils are classified as riverine alluvium and are pale brown to dark brown. They are deep, non-saline and locally calcareous. The soils at St. Theresa are stratified fine sand to loam with a high infiltration rate while those at Nakamane irrigation scheme are stratified fine sand to clay [16].

\subsection{Experimental Design}

The experiments were arranged in a randomized complete block design with a factorial arrangement and replicated three times. Treatments comprised tillage practice: conventional tillage (control), conventional tillage + mulch, and zero tillage and three selected cowpea varieties: M66, K80 and Kenkunde. Individual plots measured $4 \mathrm{~m} \times 3 \mathrm{~m}$ within each block and were separated by $0.5 \mathrm{~m}$ paths. There was $1 \mathrm{~m}$ buffer zone between blocks. Individual block measured $43 \times 3 \mathrm{~m}$ to give a total area of $129 \mathrm{~m}^{2}$ and were separated from the adjacent block by $1 \mathrm{~m}$ buffer zone. The entire experimental plot was $43 \times 17 \mathrm{~m}$ to give a total area of $731 \mathrm{~m}^{2}$. Under conventional tillage, land was prepared to a fine tilth through physical tilling before sowing at $50 \mathrm{~mm}$ depth [17]. 
In the second treatment (tillage+mulch), land was prepared to fine tilth through physical tilling before sowing at $50 \mathrm{~mm}$ depth and mulch was applied at the rate of 4 tha $-{ }^{1}[18,11]$. In the third treatment (zero tillage), land was cleared off weeds before sowing at $50 \mathrm{~mm}$ depth. Water was applied in all treatments by basin irrigation method. The gravimetric moisture was determined at the interval of seven days from top soil surface $(0-15 \mathrm{~cm})$ in the entire growth period.

\subsection{Data Collection}

Moisture retention was determined by collection of soil samples from a depth of $15 \mathrm{~cm}$ in each experimental plot. For each plot, soil was collected near the root zone of randomly selected plants. The collected samples were then weighed into $20 \mathrm{~g}$ using an electronic scale. The 54 samples were transferred into a well labeled polythene bag of known weight. The samples were air dried for three days. Weights of dry samples were recorded using the electronic balance. Soil moisture retention was then calculated using the following equation [19].

$$
\begin{aligned}
& \text { Moisture retention }= \\
& \frac{\text { Moisture treatment-Moisture control }}{\text { X }} 100
\end{aligned}
$$

\subsection{Data Analysis}

Data collected was subjected to analysis of variance (ANOVA) using the Genstat (2012) software package version 15.1. Where the $F$ values were significant, means were compared using the least significant difference (LSD) test with $5 \%$ of significance level.

\section{RESULTS}

\subsection{Effects of Tillage Practice and Variety on Moisture Retention}

Compared to the control, tillage + mulch and zero tillage conserved $37.07 \%$ and $31.63 \%$ more moisture, respectively, at St Theresa demo farm. However, at Nakamane irrigation scheme, zero tillage retained more moisture of $33.02 \%$ followed by conventional tillage + mulch at $32.24 \%$ as compared to conventional tillage.

Significant interaction was observed between tillage practice and variety at Nakamane experimental site only. The main effects of variety had no effect on moisture content.

\section{DISCUSSION}

The effect of tillage practice on moisture retention was significant in both experimental sites. Conventional tillage + mulch had higher mean moisture retention than zero tillage at St Theresa demo farm which in turn had higher moisture retention than conventional tillage. However, at Nakamane irrigation scheme, zero tillage retained more moisture followed by conventional tillage+mulch then conventional tillage. Similar results were observed by [20] who reported more water retention in zero tillage than conventional tillage. This finding was in contrast with the works of [21], who demonstrated that conventional tillage had more moisture than zero tillage. While mulched plots retained moisture by lowering soil temperature, zero tillage reduced soil moisture losses by decreasing soil capillaries that enhance evapotranspiration [22]. Zero tillage reduced moisture loss by developing a thick layer

\begin{tabular}{|c|c|c|c|c|c|c|c|c|}
\hline \multirow[t]{2}{*}{ Variety (V) } & \multicolumn{4}{|c|}{ Theresa } & \multicolumn{4}{|c|}{ Nakamane } \\
\hline & M 66 & K 80 & Ken & Mean & M 66 & K 80 & Kenkunde & Mean \\
\hline \multicolumn{9}{|l|}{ Tillage (T) } \\
\hline Conventional tillage & 0.20 & 0.21 & 0.21 & 0.21 & 0.22 & 0.21 & 0.20 & 0.21 \\
\hline 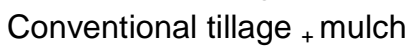 & 0.37 & 0.37 & 0.38 & 0.37 & 0.32 & 0.32 & 0.33 & 0.32 \\
\hline Zero tillage & 0.32 & 0.31 & 0.32 & 0.32 & 0.32 & 0.33 & 0.34 & 0.33 \\
\hline Mean & 0.30 & 0.30 & 0.30 & & 0.29 & 0.29 & 0.29 & \\
\hline $\operatorname{LSD}_{(\mathrm{P} \leq 0.05) T}$ & \multicolumn{4}{|c|}{$0.0192^{* *}$} & \multicolumn{4}{|c|}{$0.0074^{* *}$} \\
\hline $\operatorname{LSD}_{(P \leq 0.05)} \mathrm{V}$ & \multicolumn{4}{|c|}{$0.0192^{\text {ns }}$} & \multicolumn{4}{|c|}{$0.0074^{\mathrm{ns}}$} \\
\hline $\operatorname{LSD}_{(P \leq 0.05)} T^{*} V$ & \multicolumn{4}{|c|}{$0.0092^{\mathrm{ns}}$} & \multicolumn{4}{|c|}{$0.0129^{*}$} \\
\hline $\mathrm{CV} \%$ & \multicolumn{4}{|l|}{6.4} & \multicolumn{4}{|l|}{2.6} \\
\hline
\end{tabular}

Table 1. Effects of tillage practice and variety on moisture retention 
which restricted upward movement of water to evaporative surface by reducing diffusivity gradient. While conventional tillage improved water infiltration, it also tended to increase evaporation in control plots. In both experimental sites variety had no significant effect on moisture retention. This was attributed to little genetic variation in root biomass which substantially led to little differences in protection of the soil from increased evaporation, soil water absorption and water use efficiency. It could also be due to little above ground canopy formation differences. The results showed that tillage + mulch and zero tillage had comparative advantage over conventional tillage due to their influence on soil to hold moisture for longer period by lowering temperature [23] which reduced evapotranspiration thus making soil moisture available for plants growth.

\section{CONCLUSION}

Tillage practice has an effect on soil moisture. Conventional tillage + mulch and Zero tillage practices had higher moisture retention than conventional tillage. None of the varieties studied had influence on moisture retention. Further work is required on broader application of more tillage practices and cowpea varieties on moisture retention.

\section{COMPETING INTERESTS}

Authors have declared that no competing interests exist.

\section{REFERENCES}

1. Tessier S, Peru M, Dyck FB, Zentner FP, Campbell CA. Conservation tillage for spring wheat production in semi-arid Saskatchewan. Soil tillage research. Elsevier Science Publishers B.V., Amsterdam. 1990;18:73-89.

2. Rydberg T. Effects of ploughless tillage and straw incorporation on evaporation. Soil \& Tillage Research. Elsevier Science Publishers B.V., Amsterdam. 1990;17:303314.

3. Boone FR, Veen DE. Mechanisms of crop responses to soil compaction. In Soane, B.D. Van Ouwerkerk C. (Eds.), Soil compaction in crop production. Elsevier, New York. 1994;237-264.

4. Davis JG. Managing plant nutrients for optimum water use efficiency and water conservation. Advances in Agronomy. 1994;53:85-120.

5. Ndaeyo NU. Effects of tillage methods on growth and yields of cow pea (Vigna unguiculata (L.) Walp). M.Sc. Thesis, Dept. of Agronomy, University of Ibadan, Nigeria. 1994;123.

6. Hammel JF. Long-term tillage and crop rotation effects on bulk density and soil impendence in northern Idaho. Soil Science Society of American Journal. 1989;53:1515-1519.

7. Lal R. Tropical soils: Distribution, properties, and management. Resource Management and Optimization. 1990;7: 39-52.

8. Rashidi M, Keshavarzpour. Effect of different tillage methods on grain yield and yield components of maize (Zea mays L). International Journal of Agriculture and Biology. 2007;2:274-277.

9. Iqbal M, Hassan AU, Ali A, Rizwanullah MMM. Residual effect of tillage and farm manure on some soil physical properties and growth of wheat (Trilicium aestivum L). International Journal of Agriculture and Biology. 2005;1:54-57.

10. Jaipal S, Singh S, Yadav A, Malik RK, Hobbs PR. Species diversity and population density of macro-fauna of ricewheat cropping habitat in semi-arid subtropical northwest India in relation to modified tillage practices of wheat sowing. In: Malik R.K. Balyan R.S. Ashok Y., Pahwa S. K. (Eds) Herbicide resistance management and zero tillage in the ricewheat cropping systems: Proceeding of an international workshop. CCSHA University, Hissar, India. 2002;166-171.

11. Kinama JM, Stigter CS, Ong CK, Ng'ang'a JK, Gichuki FN. Evaporation from soils below sparse crops in contour hedgerow agroforestry in semiarid Kenya. Agricultural and Forest Meteorology Journal. 2005;130:149-162.

12. Gicheru P, Gachene C, Mbuvi J, Mare E. Effects of soil management practices and tillage systems on surface soil water conservation and crust formation on a sandy loam in semi-arid Kenya. Soil and Tillage Research. 2004;75:173-184.

13. Fernandez UO, Virto I, Bescansa P, Imaz MJ, Enrique A, Karlen DL. No tillage improvement of soil physical quality in calcareous, degradation-prone, semi-arid soils. Soil and Tillage Research. 2009; 106:29-35. 
14. Landers JN. Environmental impacts and social dimensions of zero tillage conservation agriculture in tropical Brazil.In: Goddard, T., Zoebisch, M.A., Gan, Y. T, Ellis, W., Watson, A., Sombatpanit, S. S., (Eds.) No-till farming systems. World Association of Soil and Water Conservation, Bangkok; 2008.

15. Omondi JO. Tillage and variety effects on soil moisture content, biological nitrogen fixation and soybean (Glycine $\max \mathrm{L}$. Merril) yield. Thesis, Department of Agronomy, University of Egerton, Kenya. 2013;29.

16. Sombroek WG. Braun $\mathrm{HMH}$, Vander Pouw. Kenya exploratory soil map; 1980.

17. Aikins SHM, Afuaka JJ. Growth and dry matter yield responses of cowpea to different sowing depths. ARPN Journal of Agricultural and Biological Science; 2008.

18. Hartsfield JL, Saurer TL, Prueger JH. Managing soil to achieve greater water efficiency. A Review Agronomy. 2001;93: 271-280.
19. FAO. Irrigation water management Manual; 1989.

20. Olaoye JO. Influence of tillage and cowpea residue cover on soil properties and yield components in derived Savanna ectones of Nigeria. University of Ilorin; 2001.

21. Aikins SHM, Afuakwa JJ. Effect of four different tillage practices on cowpea Performance. Journal of Agricultural Sciences. 2010;6(6):644-651.

22. Khaemba RN, Kinama JM, Chemining'wa GN. Effect of tillage practice on growth and yield of three selected cowpea varieties. Journal of Experimental Agriculture International; 2016. Article no. AJEA. 26894.

23. Kinama JM. The effects of hedgerows (alley cropping) on microclimate, soil and water conservation and competition of land use on sloping areas of Machakos Kenya, PhD Thesis, University of Nairobi Kenya; 1997.

(c) 2017 Khaemba et al.; This is an Open Access article distributed under the terms of the Creative Commons Attribution License (http://creativecommons.org/licenses/by/4.0), which permits unrestricted use, distribution, and reproduction in any medium, provided the original work is properly cited.

Peer-review history:

The peer review history for this paper can be accessed here: http://sciencedomain.org/review-history/19483 